\title{
THE ENVIRONMENTAL MANAGEMENT SYSTEM OF THE SOUTH AFRICAN NATIONAL DEFENCE FORCE AT THE GRAHAMSTOWN MILITARY INSTALLATION
}

\author{
Bheki Magagula \\ University of Fort Hare ${ }^{1}$
}

\begin{abstract}
This article presents preliminary findings on current environmental management practices used by the South African National Defence Force (SANDF) at the Grahamstown Military Installation (GMI). These findings comprise interviews with SANDF officials and an analysis of official documents, which include the first and second editions of the Environmental Management Plan for Defence (2001 \& 2008 respectively). The study on which this article reports, found that the emphasis placed on environmental protection within defence force activities worldwide has compelled the South African Department of Defence and Military Veterans (SA DODMV) to regulate the management of the environment within its properties. Yet, these efforts have faced numerous challenges that range from financial to human resources deficiencies. Consequently, the military installation at Grahamstown does not have environmentally knowledgeable and qualified personnel to deal with environmental issues. From the analysis of official documents as well as interviews with respondents, it was established that the SA DODMV itself does not have a budget for environmental services. The combination of all these drawbacks has led to the failure of the implementation of the Environmental Management System (EMS) for Defence at this military installation (i.e. GMI) of the SANDF. Undoubtedly, all these challenges have severely compromised the commitment of the SA DODMV to honour its environmental management obligations. Moreover, the deficiencies of all these resources undermine the sustainable utilisation of these

Scientia Militaria, South African Journal of Military Studies, Vol 42, Nr 2, 2014, pp. 143-163. doi : $10.5787 / 42-2-1097$

national assets (natural resources) entrusted to the defence force. The study reported here proposes an ideal model for the successful implementation of the EMS in SANDF military installations.
\end{abstract}




\section{Introduction}

Military forces around the world are faced with numerous challenges of balancing their activities with environmental concerns. This has emanated from the global increase in environmental awareness in all sectors of society. ${ }^{2}$ Defence forces around the world are therefore challenged to ensure that the effect of their activities on the environment is minimised. ${ }^{3}$ There is clear evidence that weapon testing and other military training activities have the potential to harm the environment. ${ }^{4}$

Any weapon attacking a target is capable of having a severe effect on the environment and of damaging it. ${ }^{5}$ Thus, military activities induce both severe physical disturbances in ecosystems, and chemical pollutants within and around military sites. ${ }^{6}$ Smit points out that modern-day defence forces should take the necessary action to reduce their adverse environmental impact. ${ }^{7}$ As such, many countries have started enforcing environmental management regulations within their respective properties. Consequently, defence forces across the world are expected to comply fully with environmental policies and laws governing environmental practices for the rest of the society in their respective countries. ${ }^{8}$

Many countries have responded positively to this challenge. According to Ramos and De Melo as well as Smit, these countries include the United States, Portugal, Australia, the United Kingdom, Spain, Sweden, Canada and South Africa, to name but a few. ${ }^{9}$ Most of the available literature dealing with the military and the environment is dominated by research conducted in developed countries. There is little or no literature on developing and less-developed countries respectively. Furthermore, no literature is available on the challenges of the implementation of an EMS in the military sector.

Successful implementation of an EMS in any organisation is a serious challenge in terms of both human and financial resources. Defence forces are now facing these challenges. The study on which this article is based, attempted to explore the challenges of the SANDF in implementing its own EMS and other environmental management tools within its installations. The article therefore presents preliminary results of an ongoing study being conducted at the GMI where 6 South African Infantry battalion (6 SAI Bn) is stationed.

The objectives of the study were to assess the defence environmental funding trend at the GMI, to identify the defence environmental programmes, to identify the major challenges in the implementation of environmental management tools, and to identify monitoring mechanism(s) used to measure the environmental performance at the installation. After these objectives had been reached, an ideal 
model towards the improvement of environmental practice and performance by the SANDF was developed.

\section{Research study location}

According to the unit history, ${ }^{10}$ the Grahamstown military base was established in April 1812 by the then Governor of Cradock, Lieutenant Colonel John Graham. During that time, it was a military outpost of the Cape Colony. Before 1962, around 1915 volunteers were called up to form a combat unit to execute duties in German East Africa. This military unit had three brigades formed from 12 infantry units. The 6 SAI Bn was one of the two South African Brigades.

This military unit made its first ever contact with an opposition army in 1916 (Battle of Salaita Hill). In 1941, the Royal Air Force (RAF) established the 44 Air School in Grahamstown, which was part of the British Government's Training Scheme. The 44 Air School left the Grahamstown base in 1946 after the end of the Second World War. The 6 SAI Bn was founded in January 1962, under the command of Commandant Terblanche, ${ }^{11}$ and its first intake of recruits was in April of the same year (1962). In 1993, the 6 SAI Bn received its last intake of National Servicemen. From 1994 to 1997, the unit was tasked with conducting bridging training for non-statuary forces (basic training). Members were trained and sent to various units of the SANDF. It is also reported that the unit continued to train soldiers for operational duties during that time.

In 1996, the status of the unit was changed to that of a motorised battalion. It is during this time that extensive training exercises were conducted. During the same period, the unit also participated in internal operational duties. Three years later, the status of the unit was downgraded back to that of a light infantry battalion. Two companies from this unit participated in Exercise Iron eagle in 2001, the first time the unit was used in an airmobile role by the South African Army. Despite this, the unit's participation in the exercise was successful. This meant that the unit was retained to become the airmobile battalion of the South African Army. According to the unit history, ${ }^{12}$ in 2002 , the 6 SAI Bn became the first composite battalion in the South African Military Force to be deployed beyond the borders of the country. This composite battalion was deployed on a peacekeeping mission to Burundi.

\section{Data collection}

The study adopted purposive and link-tracing sampling (LTS) techniques to select research respondents. Félix-Medina and Monjardin describe LTS as a sampling technique which is also known as 'snowball' or 'chain referral 
sampling'. ${ }^{13}$ Katuu refers to snowball sampling as a referral form of a data collection technique. ${ }^{14}$ Using these research methods, the selection of respondents to participate in the study was based on appropriateness and environmental management responsibility within the military unit. Therefore, only those individuals who were in a position to provide relevant data to achieve the objectives of the study were identified by the initial sample of members of the target population. LTS has proved to be appropriate for sampling hidden respondents within the targeted population. ${ }^{15}$ Sheng, Hsu and $\mathrm{Wu}$ also attest to the fact that LTS is the only means by which initially sampled respondents lead the researcher to other potential/hidden respondents within the population, which, in turn, may lead to other respondents. ${ }^{16}$ The current study successfully used purposive sampling and LTS (snowball sampling) to identify relevant respondents within the SANDF members stationed at GMI. Consequently, only military personnel who were charged with the responsibility to ensure that military activities were carried out in compliance with environmental legislations were interviewed. The targeted respondents were the personnel in the Environmental Management Facility (EMF) at the GMI. The LTS technique was then used to identify other individuals who could provide relevant data to this study, other than those at the EMF.

A semi-structured interview guide was designed and used to collect the data. This guide categorised questions into five sections, namely financial resources, human resources, legislation, internal policies and environmental management structure, and linkages. A total of seven military officials were interviewed. Only one official refused to be interviewed. The first interview was held with the occupation, health and safety officer on 1 July 2011. The health and safety officer referred the researcher to all the other respondents. An interview was conducted on 12 July 2011, with a non-commissioned staff officer of the Environmental Services Division based in Pretoria, who was visiting the GMI to determine whether appropriate environmental impact mitigation measures were in place before the start of Exercise Shared Accord between the SANDF and the US Marine. This interview took the form of an informal discussion; however, notes were taken during the interview and refined after the discussion. Interviews were also held with the military readiness officer, as well as the acting environmental non-commissioned officer based at GMI. These interviews were held on 13 July 2011. On 14 July 2011, the occupation, health and safety officer was interviewed for the second time, just to get more clarity on certain issues he raised during the first interview session. These interviews aimed at eliciting data on measures taken to prevent pollution as a result of vehicle breakdown and fixing during training exercises. All these interviews were tape-recorded and transcribed in extenso thereafter. Respondents were adamant 
about not talking 'on record', but were assured that whatever information they provided would be treated as confidential and for research purposes only.

Additional data were gathered during an informal discussion with the regional environmental manager. In addition to the semi-structured interviews, the study also used document analysis. The documents analysed included two environmental implementation plans (EIPs) (i.e. the first edition of 2001 and the second edition of 2008) and relevant legislation (highlighted in the Legal Framework section below). The purpose of studying the EIPs was to establish the mechanisms by which the SA DODMV was planning to deal with environmental issues within its territories. Relevant pieces of legislation were reviewed to establish the legal mandate for the environmental management of all sectors (including the SA DODMV) of the South African society. Both narrative and discourse data analysis were used to analyse the data collected.

\section{Results and discussion}

For the SANDF to integrate environmental protection practices effectively into its activities and to improve its environmental performance, it needs to plan and budget accordingly. It became evident from the interviews that five critical elements needed to be considered in the military environmental management planning process. These included appropriate financial planning and allocation, acquisition of skilled human resources, strengthening of internal organisational structures for coordination purposes, updating internal policies in line with the national legal framework and establishing and maintaining external linkages with environmental experts and practitioners. These issues are discussed in the sections below.

\section{Funding}

Environmental funds are one of the most important tools for the effective implementation of environmental management in any organisation. According to Wang, ${ }^{17}$ availability of financial resources is a cause of effective environmental management. Thus, private organisations have what they call 'social responsibility funds' which are used to finance external environmental management programmes. The democratic government of South Africa has promulgated numerous laws for the protection and sustainable utilisation of the country's natural resources. Some of these legislative provisions governing the daily practices of defence are discussed in the section on the legislative framework below.

The interview with the senior staff officer - Environmental Management Services and the analysis of both EIPs (2001 \& 2008 editions) revealed that, generally, the entire DODMV does not have a specific budget for its environmental programmes and services. As a result, even the SANDF does not have a budget 
allocation for environmental management services. Environmental services at the GMI are funded from a miscellaneous account. This practice does not promote effective and adequate environmental management by the defence force. It also does not encourage sustainable utilisation of the natural resources within defence installations, as can be seen at the GMI.

Defence forces in other countries do have an environmental budget. For example, the US Department of Defence (US DOD) spends billions of dollars on environmental programmes every year. ${ }^{18}$ Similarly, countries such as Portugal, Australia, the United Kingdom, Spain, Sweden and Canada adequately fund environmental management efforts of their respective defence forces. ${ }^{19}$

In the SANDF, the costs associated with environmental management in defence activities have not been sufficiently internalised and are integrated with expenditure associated with other functions. As a result, this has obscured the true environmental expenditure of the SANDF. ${ }^{20}$ Indeed, the GMI could not show evidence of environmental expenditure for its environmental management services. Moreover, there should be specific environmental management programmes at each installation linked to the EMS or advancing the corporate environmental statement of the SA DODMV. Officials involved in the management of the environment at the GMI stated that it is very difficult to get funding for environmental managementrelated activities. Obviously, such situations discourage the defence force members who are responsible for the environment. These people cannot be expected to provide leadership in ensuring that the environmental impact of defence activities is minimised to an acceptable level if the necessary resources are not made available

This lack of funding is astonishing because the first directive to the SANDF to care for the environment under its control was issued in 1977 already. ${ }^{21}$ This instruction led to the development of the first environmental policy for the South African Defence Force (SADF) in $1978 .^{22}$ By now, all environmental facilities of the SANDF should have been fully operational and well resourced. For more than three decades, the SANDF has failed to plan properly to finance environmental management programmes. Consequently, the GMI did not have an ongoing environmental management programme, linked to the implementation of the EMS for defence. This indicated that the SANDF was facing serious challenges in the implementation of the EMS at the GMI, mainly because of insufficient resources to sustain the environmental services, which is a critical factor in the successful implementation of environmental management tools.

Abrahams points out that the defence budget has been gradually decreasing every year. ${ }^{23}$ This could be associated with other priorities of government, including building houses, schools, clinics, infrastructure (water, power supply to rural areas, 
roads), etc. Considering the importance and urgency of these challenges, it really makes perfect sense to rank them high on the priority list over and above environmental protection from military activities. It will only be after all these basic necessities had been addressed that the focus can shift towards environmental protection. $^{24}$

Wang points out that financial resource is a foundation of effective environmental management. ${ }^{25}$ It is therefore imperative that the SA DODMV find an alternative source of funding to make available sufficient funds to finance its environmental needs and programmes for the protection and promotion of environmental sustainability. For example, Poland has developed what is called Environmental Funds, which are aimed at improving the implementation of its National Environmental Policy. ${ }^{26}$ The revenue sustaining these funds comes from various sources, including environmental fees, fines for breaching environmental regulations and non-compliance, banks and the Global Environmental Facility and so on. According to the Organisation for Economic Co-operation and Development (OECD), finding additional sources of funding for environmental policy implementation is very important to offset budgetary cuts in the short to medium term. ${ }^{27}$ The South African government can also develop a similar scheme to offset setbacks created by budgetary cuts, to assist the SANDF, in particular in its quest to meet its environmental management obligations. Defence force activities are by nature aggressive; therefore, it is important that the SANDF must have an effective environmental management strategy. Moreover, the implementation of the strategy hinges strongly on the availability of all forms of resources.

\section{Personnel}

As of July 2011, the GMI did not have environmentally qualified and competent staff in its environmental management facility. The majority of the personnel at the facility did not even have a working knowledge of environmental management issues. These are the people who are expected to provide guidance on the incorporation of environmental concerns into military activities at all times. Smit reports that the national service system had been terminated and that the present environmental services personnel structure consists of permanent force members. ${ }^{28}$ This has provided the much-needed continuity in dealing with environmental issues in defence. ${ }^{29}$ However, it was established that the GMI has been without a permanent environmental officer for approximately two years. Clearly, there is an urgent need for the SANDF to develop and/or enhance the competence of its environmental management staff if it is to succeed in honouring its environmental obligation. 
It must also be borne in mind that the successful implementation of EMS within the SANDF depends largely on the environmental capabilities of the members of the defence force. The members are the most important resource upon which the success or failure to translate environmental policies, plans and programmes depends. Without environmentally qualified and competent staff the SANDF will not be able to achieve its aim of implementing EMS and adequately incorporating environmental concerns into all its activities. Competent staff can positively change the attitude of all defence force members to a 'can-do' attitude towards environmental issues and challenges.

Environmentally informed defence force members can also change the reactive attitude of all defence force members towards environmental issues to a proactive one. Given the current situation at the GMI, it is important that personnel attached to the environmental management facility receive training in environmental issues to capacitate them. It is only then that these defence force members can provide genuine leadership on environmental matters across the full spectrum of environmental issues at the military installation. The current state of affairs indicates that there is a lack of commitment to effective management and protection of the environment from military activities at this installation. Above all, this affirms the notion expressed by Rao that environmental management is not one of the primary concerns of military forces. ${ }^{30}$ This is the attitude that the military sector needs to change gradually. In addition, the military sector needs to have its activities streamlined with environmental protection and sustainability in mind. Moreover, environmental management may prove critical in land used primarily to support field training requirements for combat readiness. ${ }^{31}$ This is vital because effective military training requires a landscape with natural land features. ${ }^{32}$ Degraded training ranges may adversely affect the potential for diversified military training. Lewis argues that access to high-quality training areas serves as a third factor (in addition to time and money) in troops' readiness. ${ }^{33}$

\section{Structures}

When the research for this study was done in 2011 the GMI did not have any environmental management and performance monitoring mechanisms. There were no environmental audits and/or annual environmental management reports. This suggests that the SANDF's operating procedures at this installation have not evolved sufficiently to incorporate environmental protection practices. It also shows that the impact of military activities at this installation was not satisfactorily monitored and evaluated. This was still happening in 2011, even after more than a decade since the SANDF participated in a pilot study on the implementation of an EMS in the military sector by the North Atlantic Treaty Organisation's Committee on the 
Challenges of Modern Society (NATO-CCMS) in 1996-1999. The final report of the NATO-CCMS's pilot study on the implementation of systematic environmental management to defence forces concluded that it is possible and even desirable to implement EMS in military organisations, given the destructive potential of military activities. $^{34}$

The environmental practice or lack thereof at the GMI also contradicts both the first and second editions of the EIP of the SA DODMV published in 2001 and 2008, respectively. Both the EIP documents state that the implementation of environmental management and performance by the defence force as well as compliance with legislation will be monitored. The monitoring mechanisms suggested include an environmental audit and an annual environmental report, to name but two. ${ }^{35}$

However, it is important to note that environmental problems in South Africa are both First and Third World in nature. ${ }^{36}$ The First World environmental problems characterising South Africa include acid rain, which emanates from pollution of the atmosphere through industrial emissions of greenhouse gases (GHGs), such as sulphur dioxide $\left(\mathrm{SO}_{2}\right)$ and nitrogen oxides $\left(\mathrm{NO}_{\mathrm{x}}\right)$, as a result of combustion of fossil fuel in coal power generating plants. Contamination and/or pollution of water through acid mine drainage (AMD) is another form of environmental problem common in First World countries, which has also become one of the major environmental problems in South Africa. AMD has affected numerous ecosystems and polluted many major rivers and other water sources in the United States, England, Wales and Spain (which are First World countries). ${ }^{37}$ Similarly, AMD from defunct mine shafts has also become a major environmental threat in South Africa since the turn of the century. ${ }^{38}$ The Third World environmental problem in South Africa relates to solid waste management. Waste management challenges in South Africa range from strategic waste management issues at national government level to basic operational challenges at local government level. ${ }^{39}$ Large metropolitan municipalities provide a relatively complete waste management service, including collection and appropriate disposal. However, the same cannot be said about many smaller municipalities in rural areas, which lack the capacity to deliver any waste management services to the residents. ${ }^{40}$ Furthermore, South Africa is still grappling with social problems associated with the provision of clean and safe drinking water and sanitation facilities to thousands of the populace, as well as environmental problems. Thus, the government is unable to deal effectively with environmental problems by enforcing environmental regulations at the expense of human welfare. ${ }^{41}$ Government does not have adequate resources to monitor compliance with existing legislation, given all the above mentioned challenges. Thus, at the time of the study, the GMI had never been 
audited by an 'external' environmental management monitoring agency such as Environmental Management Inspectorate (EMI) inspectors. Even the proposed internal environmental management mechanisms suggested in the 2008 EIP were not adequately followed.

\section{Legal framework}

In 2005, the Department of Environmental Affairs and Tourism (DEAT) formed the Environmental Management Inspectorate (EMI). The EMI units were formed with the aim of monitoring compliance and enforcement of environmental legislation and regulations (including authorisation issued under legislation in their mandate).$^{42}$ These units were given the powers to enter any property unannounced in order to conduct environmental inspection. Such inspection is carried out to enforce the following legislation:

- Firstly, the Environment Conservation Act (ECA), 1989 (Act No. 73 of 1989, which, although promulgated during the apartheid era, is still relevant) and which requires that the environment must be adequately protected, environmental pollution prevention must also be prioritised and that waste be properly managed. ${ }^{43}$

- Secondly, the Constitution of the Republic of South Africa (Act No. 108 of 1996), particularly Section 24 of the Bill of Rights, which makes provision for the protection of the environment. In part, this section states, "[E]veryone has the right -

(a) to an environment that is not harmful to their health or wellbeing; and

(b) to have the environment protected, for the benefit of present and future generations, through reasonable legislative and other measures that -

(i) prevent pollution and ecological degradation;

(ii) promote conservation; and

(iii) secure ecologically sustainable development and use of natural resources while promoting justified economic and social development. $" 44$

- Thirdly, in the National Environmental Management Act (NEMA) (Act No. 107 of 1998), the principles under Section 2 of this Act describe how policies, plans and programmes of any organisation should comply with the NEMA. ${ }^{45}$

- Fourthly, the National Environmental Management: Biodiversity Act, 2004 (Act No. 10 of 2004). ${ }^{46}$ Under this Act, the SANDF must have an 
ecological management plan for all its military installations. ${ }^{47}$ Without such plans, the protection and maintenance of biodiversity within military areas cannot be guaranteed.

- Fifthly, the National Environmental Management: Protected Areas Act, 2003 (Act No. 57 of 2003). Under this Act, the defence force must have guidelines and procedures to promote, protect and conserve the ecological integrity of ecosystems in military sites. ${ }^{48}$

- Finally, National Water Act, 1998 (NWA) (Act No. 36 of 1998) was promulgated to protect the water resources in the country. Under this Act, the defence force must have and implement water pollution prevention measures to ensure that this scarce resource is not degraded through various forms of pollution. ${ }^{49}$

These Acts all advocate the protection, pollution prevention and sustainable utilisation of the country's natural resources. Ideally, the defence force is expected to comply with all these legislative provisions. The principles of NEMA together with all the other legislative provisions do not exempt the SA DoDMV from adequately managing the environmental within its territories, and no clause(s) in any of these provide such exemption to the DoD. At the time of the study in July 2011, the practices at the GMI appeared not to be in compliance with these legislative provisions.

The integrated environmental management (IEM) concept was adopted in South Africa in 1989 as a tool to be used to assess environmental concerns. ${ }^{50}$ The IEM was adopted because its primary objectives were to promote environmentally sound utilisation, and to link the opposing concepts of utilisation of natural resources and conservation, placing emphasis on saving the resource base for future generations. ${ }^{51}$ In other words, the IEM emphasised a reduction in severe environmental impacts through eliciting information from diverse stakeholders, thereby promoting the sustainability of natural resources. This principle applies across the board and to all the diverse sectors of South African society.

Every sector in South Africa is expected to conduct its business within the ambit of the above-mentioned legal frameworks and many others not mentioned here.

However, it appears that the SANDF is exempted from such inspection, or the EMI units do not exercise their powers to audit the environmental performance of the defence force. Bertell rightly points out that states tend to operate a double standard. They are not willing to subject their defence forces to the level of transparency and accountability that is required of other organs of state and civil 
society. ${ }^{52}$ If this is true, the lack of transparency and accountability is unacceptable because all sectors of the society must abide by the laws and regulations of the country in an effort to promote environmental protection and sustainability of natural resources.

Avis correctly points out that in South Africa, the private sector is fairly controlled but the public sector is not. ${ }^{53}$ Given the political nature of the defence force, enforcement of environmental regulations and compliance with legislations are not stringent. This means that the agencies charged with the responsibility of monitoring the environmental performance, and compliance with legislations and regulations were not assessing and evaluating practices of the SANDF at the time of the study, at least not at the GMI.

Glazewski argues that South Africa is a typical example of a country where there is significant discrimination in the enforcement of environmental management legislations and regulations. ${ }^{54}$ This implies that environmental performance and practises of the private sector are strictly monitored but in most cases, activities of government departments are not rigorously compelled to comply with the same legislations and regulations.

In addition, at the time of the study, Defence's institutional framework on environmental matters appeared to be weak. The senior staff officer of the SANDF in the environmental management services of the defence force stated that it was difficult to enforce environmental compliance within the defence force due to policy-related challenges or weaknesses. The existing environmental policy of the SA DODMV was still fragmented. ${ }^{55}$ This did not promote integration of environmental management and concerns in all the activities of the defence force at all installations. It also indicated failure of the SA DODMV to comply with environmental legislation. Moreover, this also reflected the failure of the South African government to enforce its environmental management law indiscriminately across all the sectors of society. Worse of all was the lack of environmentally competent staff at the GMI. This was a serious weakness and a significant drawback for attempts by the defence force to improve its environmental management practice profile. The absence of competent staff at GMI consequently had a negative effect on the translation of plans/programmes of the SA DODMV into action.

Good policy documents and plans are meaningless if not implemented. The study found that SA DODMV was failing to lead by example on environmental management issues, yet it was one of the major landowners in South Africa. This department controls approximately $0.4 \%$ of state-owned land. ${ }^{56}$ The Portuguese military sector owns more than $0.25 \%$ of the land, ${ }^{57}$ the United States Army manages approximately $1.25 \%$ of land, ${ }^{58}$ and the Australian defence force is also the 
largest landowner (1.69\%) in Australia. ${ }^{59}$ Defence forces in all these countries have successfully implemented an EMS to ensure that they comply with the environmental laws and regulations of their respective countries, ${ }^{60}$ thus mitigating their impact on the areas under their control. At the GMI, the SANDF was failing to accomplish this at the time of the study.

Compliance with environmental management legislations is an assurance that future generations will be able to continue utilising the same land area for the same purposes. Therefore, all South African government departments which have the potential to harm the environment through their activities are expected to be exemplary in environmental protection and promotion of sustainable utilisation of natural resources by being proactive rather than reactive (i.e. to comply fully with environmental legislations and regulations). This will give the government the moral high ground to force private companies and firms to comply with these legislations and regulations as well. Laws and regulations should not be implemented selectively, but should be enforced uniformly across the board whether the activity is carried out by a government department or by a private firm/company. Nonenforcement and compliance by government departments create a situation where the whole concept of environmental sustainability, especially within defence territories, becomes a myth or mirage.

Thus, non-monitoring of environmental performance and compliance with legislations and regulations by the SANDF violates Section 28 of the NEMA (1998), which requires every person causing significant impact (pollution or degradation of) on the environment, to take all reasonable measures to prevent it from occurring, continuing or recurring. Defence activities have a great potential to harm the environment. It was therefore recommended that the GMI develop programmes and plans in line with the mitigation of environmental impacts as well as performance monitoring mechanisms as required by the environmental management law (i.e. NEMA of 1998) as well as the second edition of the EIP for the defence.

\section{External linkages}

Another major weakness noted, was that the environmental facility at the GMI did not collaborate with any of the institutions of higher learning and other research institutions. The lack of collaboration with universities and research institutions as well as other environmental experts, severely hampered the implementation of effective environmental management measures at this military installation. Moreover, it was found that interaction with other stakeholders could even improve the defence force members' understanding of environmental issues. 
Stakeholders also play a major role in environmental management processes in the private sector. This role needs to be recognised in the public sector, including defence activities. ${ }^{61}$ This can only be realised if the defence force could be more transparent and inclusive on environmental management issues. The Australian Department of Defence prioritises external linkage with environmental stakeholders and maintains transparency on environmental issues. ${ }^{62}$ Collaboration has the potential to assist the defence force to develop effective management tools, as well as in the evaluation of the defence environment management practices and performance. ${ }^{63}$

The interaction between defence force members and external environmental experts and practitioners could have a variety of other benefits. These may include the accurate interpretation of policies and directives, and keeping abreast of the best environmental practices. ${ }^{64}$ Adequate interpretation of documents and directives will mean that these are easily translated into plans and action. It was clear that the lack of adequate funding, the lack of competent staff as well as a lack of external linkages posed a significant challenge to the protection of the environment at this installation.

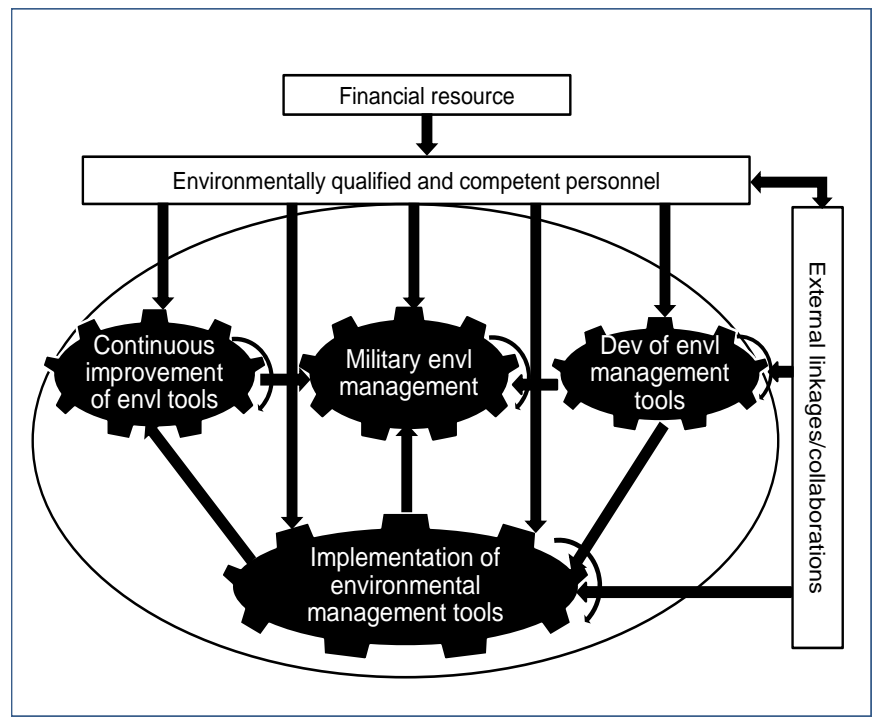

Figure 1: Proposed model towards the implementation of the EMS in the defence ${ }^{65}$

As indicated in Figure 1, the other critical issue in the implementation of EMS and effective management of the environment in the defence force is maintaining external linkages. Non-availability of financial resources and an 
absence of interaction with external environmental experts and practitioners could lead to poor environmental practises as well as failure or collapse of the whole effort to implement an EMS within SANDF military activities. The collapse of the implementation of EMS would be a major setback for the DoDMV in its quest to honour its environmental obligations. There was evidence that some military training areas of the SANDF are showing signs of degradation. Harmse also reports that military training areas in the province of Limpopo (one of South Africa's nine provinces) have been affected by severe soil erosion. ${ }^{66}$ The severity of the problem has prompted the SANDF to seek scientific assistance from experts to deal effectively with the problem. ${ }^{67}$ This would not have happened if the SANDF had been resourced well enough to deal with integrating environmental issues to military programmes and practice. ${ }^{68}$

Figure 1 illustrates the essential components of a realistic process towards the implementation of an EMS. Finances are critical towards the successful implementation of any project. When there is adequate funding for any programme it becomes easier to attract, hire and retain skilled and competent personnel. These are the people who should interpret defence policies and programmes and translate these into action. Furthermore, their primary function should include developing various environmental management programmes/plans and providing leadership in the implementation of environmental management programmes in their respective military units/installations.

In addition, defence's environmental officers must carry out environmental management audits and measure the performance of their respective units against the set objectives and targets. This will ensure continuous improvement of environmental performance (indicated by the curved arrows in Figure 1). Qualified personnel have to foster a sense of environmental accountability among defence force members. Most importantly, qualified and competent personnel need to establish and maintain external linkages and/or collaborations with experts, practitioners and other institutions. This is crucial towards the formulation of best practices, which are applicable to and compatible with military activities. Moreover, the external stakeholders could also assist in the formulation and implementation of environmental management techniques and evaluate adopted tools.

External stakeholders could provide an objective assessment of the environmental performance of the SANDF. A continuous evaluation of environmental management programmes should be carried out to ensure their relevance towards achieving the sustainability of all military training areas and environmental protection from aggressive military activities. These exercises are meant to identify strengths and weaknesses of the management tools. The other 
positive aspect of networking with experts and practitioners is accessibility to cutting-edge information and current developments in the environmental management field. An adoption of this model could lead to the successful implementation of the EMS for defence, which will significantly improve the SANDF's environmental practice and performance at all military installations.

\section{Conclusion}

The SANDF is not taking its obligation to protect the environment seriously enough. Although the directive to manage the environment within its territories was issued more than thirty years ago (i.e. in 1977), ${ }^{69}$ it was clear that the GMI had not yet responded positively to this call at the time of the study in 2011. This was in conflict with the environmental legislation of the country and the stated objectives of the DoDMV environmental policy statement. If the SANDF had been serious about incorporating environmental issues into its activities, it would have planned and developed an environmental management budget for all its environmental services over the years. However, it is also imperative to acknowledge that the defence budget has been shrinking over the years from R19, 6bn (4.3\% of GDP) in 1989 to R10, 5 bn (2.2\% of GDP) in $1995 .{ }^{70}$ However, the defence budget started increasing from the year 2000 onwards. In the 2000/01 financial year, the defence was allocated R13, 8bn, and R37, 5bn in 2012/13 financial year. ${ }^{71}$ The increase in the defence budget is linked to the African Agenda the South African government is pursuing (i.e. the peacekeeping mission in the African continent).

Having said that, it does not forestall the obligation to secure funds for the implementation of the EMS for defence. To offset the budgetary cuts which have characterised the past years' budget allocation by approximately $11.4 \%$ in 1990 to $14.6 \%$ in $1995^{72}$ and to sustain its environmental funds, the DoDMV could approach the Global Environmental Facility (GEF) and the Development Bank of Southern Africa (DBSA) through government to seek additional funds. The lack of such funds implies that the environment has not received the high priority it deserves from this department. Government itself has also failed to establish a similar fund from all the taxes, environmental fees and fines that are being collected from environmental defaulters. Such a fund could have helped the SANDF to meet its environmental obligations more effectively.

South African environmental laws emphasise the polluter-pays principle. Adequate enforcement of these laws would generate sufficient funds for government to establish an environmental fund. This fund can then be used towards financing the implementation of environmental legislations and regulations within departments that are struggling to finance environmental programmes from their allocated 
budget. Adequate financial resources are crucial to all efforts to implement environmental management tools.

Environmentally qualified staff/personnel can only be attracted and retained when adequate funding is available. These are the people who must be able to interpret policies and directives and translate them into action plans. They also have to interact with experts and practitioners outside the defence force to keep abreast with developments in environmental management matters. This interaction will also assist them to develop effective impact mitigation measures at, or for, each installation. Staff at the military environmental management facility of the defence force must provide leadership on environmental management issues at all times. Therefore extensive environmental awareness training and education for the SANDF members are imperative to instil a proactive and can-do attitude. The study found that environmental practices at GMI nullified what the 2001 and 2008 EIP documents articulate, and violated the environmental management legislations. The SANDF must therefore engage in collaborations and partnerships with relevant institutions as well as practitioners to improve its environmental performance and management practice profile.

The lack of sufficient financial resources, competent staff and external linkages were the major shortcomings and challenges that have led to the failure to implement an EMS at the GMI.

\section{Endnotes}

${ }^{1}$ This research article is based on a project supported financially by the National Research Foundation (NRF) in conjunction with the Govan Mbeki Research Development Centre (GMRDC) of the University of Fort Hare. I am very grateful for their support. I would like to extend my gratitude to Dr Solomon Tesfamichael and to Prof. Werner Nel and Comm. Hennie Smit for their constructive comments on this research article. A special thanks is extended to Mr Thulani Mndebele for editing this article.

${ }^{2}$ Smit, HAP. "Shaping the environmental attitude of military geography students at the South African Military Academy". Journal of Geography in Higher Education 33/2. 2009. 225-240 and Wu, W \& Wang, XH. "Development of an environmental performance indicator framework to evaluate an environmental management system for Shoalwater Bay Training Area, Queensland, Australia". Labour and Management in Development Journal 11. 2011. 1-20.

${ }^{3}$ Smit, "Shaping the environmental attitude ..." op. cit.

${ }^{4}$ Lindsay-Poland, J \& Morgan, N. "Overseas military bases and environment". 1998. <http://www.fpif.org/briefs/vol3/v3n15mil.html> Accessed on 20 November 2006. 
5 Tikhomirov, SN. "1939-1945: Environmental aspects of war in Europe". Review of Central and East European Law 31. 2006. 111-125.

${ }^{6}$ Linkov, I, Grebenkov, A \& Baitchorov, VM. "Spatially explicit exposure models: Application to military sites". Toxicology and Industrial Health 17. 2001. 230-235.

7 Smit, "Shaping the environmental attitude ..." op. cit.

8 Ramos, TB \& De Melo, JJ. "Environmental management practices in the defence sector: Assessment of the Portuguese military's environmental profile". Journal of Cleaner Production 13. 2005. 1117-1130.

9 Ramos, TB \& De Melo, JJ. "Developing and implementing an environmental performance index for the Portuguese military". Business Strategy and the Environment 15. 2006. 71-86; Smit, "Shaping the environmental attitude ..." op. cit. and Smit, HAP. "The development of an environmental approach in the South African Department of Defence". In Häusler, H \& Mang, R (eds), International handbook military geography 2. Proceedings of the $8^{\text {th }}$ International Conference on Military Geosciences, June 15-19, 2009. Vienna: Arbeitsgemeinschaft Truppendienst, Ministry of Defence and Sports, 2011. 478-486.

${ }^{10}$ South African Department of Defence. "6 South African Infantry Battalion Unit History of the Unit". Pretoria, n.d

${ }^{11}$ Note: Initials of Commandant Terblanche are unknown.

${ }^{12}$ South African Department of Defence. "6 South African Infantry ...” op. cit.

${ }^{13}$ Félix-Medina, MH \& Monjardin, PE. "Link-tracing sampling with an initial sequential sample of sites: Estimating the size of a hidden human population”. Statistical Methodology 6. 2009. 490-502.

${ }^{14}$ Katuu, S. "Enterprise Content Management (ECM) implementation in South Africa". Records Management Journal 22/1. 2012. 37-56.

${ }^{15}$ Félix-Medina \& Monjardin, "Link-tracing sampling with an initial ..." op. cit.

${ }^{16}$ Sheng, ML, Hsu, C \& Wu, C. "The asymmetric effect of online social networking attribute-level performance”. Industrial Management \& Data Systems 111/7. 2011. 1065-1086.

${ }^{17}$ Wang, X. "Exploring trends, sources, and causes of environmental funding: A study of Florida counties". Journal of Environmental Management 92. 2011. 2930-2938.

18 United States Department of Defense. Defense Environmental Programs. Fiscal year annual report to Congress, 2004.

19 Ramos \& De Melo, "Developing and implementing ..." op. cit.

20 Department of Defence. Environmental Implementation Plan for Defence $\left(2^{\text {nd }}\right.$ ed). Pretoria, 2008.

21 Ibid. and Smit, "Shaping the environmental attitude ..." op. cit.

22 Godschalk, SKB. "Green soldiering: Integrated environmental management as a major contribution towards military mission achievement". Paper presented at the $14^{\text {th }}$ International Logistics Congress, Sun City, 25 November 1998.

23 Abrahams, D. "Military base conservation in South Africa: Opportunities for local economic development". Urban Forum 19. 2008. 43-60. 
24 Harmse, T. "War and the environment". 2003. <http://general.rau.ac.za/aambeeld/julie2003/tertiusharmse.htm> Accessed on 5 February 2007.

${ }^{25}$ Wang, "Exploring trends, sources, and causes ..." op. cit.

${ }^{26}$ Unido.org. "Environmental funds". <http://www.unido.org/index.php?id=5328> Accessed on 2 July 2012.

27 Organisation for Economic Co-operation and Development (OECD). "Funding environmental compliance assurance: Lesson learned from international experience". 2005. <http://www.oecd.org/dataoecd/51/58/35139072.pdf> Accessed on 2 July 2012.

${ }^{28}$ Smit, "The development of an environmental approach ..." op. cit.

29 Ibid.

${ }^{30}$ Rao, NH. "Environmental management: Relevance and implications for management of defence installations for sustainability". Current Science 88/11. 2005. 1753-1758.

${ }^{31}$ Ibid. and Ramos \& De Melo, "Environmental management practices ..." op. cit.

${ }^{32}$ Ramos \& De Melo, "Environmental management practices ..." op. cit.

${ }^{33}$ Lewis, J. "The impact of environmental degradation on troop readiness: Causes, public perception and policy". Canadian Army Journal 12/3. 2010. 99-101.

${ }^{34}$ NATO-CCMS (North Atlantic Treaty Organisation, Committee on the Challenges of Modern Society). Pilot study on environmental management systems in the military sector. 2000.

<http://www.nato.int/science/publication/publi/envmil/envmil2.pdf> Accessed on 21 April 2009 and Dawson, M. "Environmental Management Systems (EMS) in the military sector: Promoting broader implementation". In Mahutova, K, Barich, JJ \& Kreizenbeck, RA (eds), Defense and the environment: Effective scientific communication, Berlin: Kluwer, 2004, 7583.

35 Department of Defence. Environmental Implementation Plan for Defence. Pretoria, 2001 and Lewis, J. "The impact of environmental degradation on troop readiness: Causes, public perception and policy". Canadian Army Journal 12/3. 2010. 99-101.

${ }^{36}$ Glazewski, J. "Environmental provisions in a new South African Bill of Rights". Journal of African Law 37/2. 1993. 177-184.

${ }^{37}$ Caraballo, MA, Macías, F, Rötting, TS, Nieto, JM \& Ayora, C. "Long term remediation of highly polluted acid mine drainage: A sustainable approach to restore the environmental quality of the Odiel river basin". Environmental Pollution 159. 2011. 3613-3619.

${ }^{38}$ Davies, TC \& Mundalamo, HR. "Environmental health impacts of dispersed mineralisation in South Africa”. Journal of African Earth Sciences 58. 2010. 652-666.

${ }^{39}$ Godfrey, L. "Facilitating the improved management of waste in South Africa through a national waste information system". Waste Management. 28. 2008. 1660-1671.

${ }^{40}$ Friedrich, E \& Trois, C. "Greenhouse gases accounting and reporting for waste 
management: A South African perspective". Waste Management 30. 2010. 2347-2353.

${ }^{41}$ Glazewski, "Environmental provisions in a new..." op. cit.

${ }^{42}$ Fourie, M. "The National Environmental Management Act (NEMA) and the Environmental Inspectorate". Presentation to Prosecutor Training Course, Department of Environmental Affairs and Tourism (DEAT), Pretoria, 25 July 2005.

${ }^{43}$ Republic of South Africa. Environment Conservation Act (ECA) (Act No. 73 of 1989). Pretoria, 1989.

${ }^{44}$ Republic of South Africa. The Constitution of the Republic of South Africa (Act No. 108 of 1996). Pretoria, 1996.

${ }^{45}$ Republic of South Africa. The National Environmental Management Act (NEMA) (Act No. 107 of 1998). Pretoria, 1998.

${ }^{46}$ Republic of South Africa. Biodiversity Act (Act No. 10 of 2004). Pretoria, 2004.

47 Ibid.

${ }^{48}$ Republic of South Africa. Protected Areas Act (Act No. 57 of 2003). Pretoria, 2003.

${ }^{49}$ Republic of South Africa. The National Water Act (Act No. 36 of 1998). Pretoria, 1998.

${ }^{50}$ Sowman, M, Fuggle, R \& Preston, G. "A review of the evolution of environmental evaluation procedures in South Africa". Environmental Impact Assessment Review 15. 1995. 45-67.

${ }^{51}$ Avis, AM. "Integrated environmental management and environmental awareness in South Africa: Where are we going?" Journal of Environmental Planning and Management 37/2. 1994. 227-243.

${ }^{52}$ Bertell, R. The military's impact on the environment: A neglected aspect of the sustainable development debate. A briefing paper for state and nongovernmental organisations. Geneva: International Peace Bureau, 2002.

53 Avis, "Integrated environmental management ..."op. cit.

${ }^{54}$ Glazewski, "Environmental provisions in a new..." op. cit.

${ }^{55}$ Department of Defence, "Environmental Implementation Plan ..." ( $2^{\text {nd }}$ ed) op. cit.

${ }^{56}$ Department of Defence. White Paper on National Defence for the Republic of South Africa. Pretoria, May 1996.

${ }^{57}$ Ramos \& De Melo, "Developing and implementing ..." op. cit.

${ }^{58}$ Johnson, S, Wang, G, Howard, H \& Anderson, AB. "Identification of superfluous roads in terms of sustainable military land carrying capacity and environment". Journal of Terramechanics 48. 2011. 97-104.

${ }^{59}$ Australian Government Department of Defence. Defence Environmental Strategic Plan, 2010-2014. Defence Support Group, 2010 and Wang, "Exploring trends, sources, and causes ..." op. cit.

${ }^{60}$ Australian Government Department of Defence. Defence Environmental Strategic ... "op. cit.

${ }^{61}$ Ramos \& De Melo, "Developing and implementing ..." op . cit.

${ }^{62}$ Australian Government Department of Defence op. cit.

63 Ibid. 
64 Ibid.

${ }^{65}$ Note: Envl stands for 'environmental'; Dev. stands for 'development'; curved arrows denote 'continuous update' or 'continuous improvement'.

${ }^{66}$ Harmse, "War and the environment ..." op. cit.

${ }^{67}$ Ibid.

68 Ibid.

${ }^{69}$ Godschalk, SKB. "Green soldiering: Integrated environmental management ..." op. cit.; and Smit, HAP. "The development of an environmental approach ..." op. cit.

${ }^{70}$ Batchelor, P, "South Africa's Arms Industry: Prospects for Conversion”. In Cock, J, \& Mckenzie, "From Defence to Development: Redirecting Military Resources in South Africa", Cape Town, David Philip. 1998

${ }^{71}$ Sisulu, LN, Minister of Defence and Military Veterans on the occasion of the "Department of Defence Budget Vote", 17 May 2012.

<http://www.dod.mil.za/ministry/media_statements/2012/BudgetVote 2012> Accessed on 10 October 2014; and Parliamentary Monitoring Group. "Defence Budget 2000 - 2004".

<http://www.pmg.org.za/minutes/20001003-defence-budget-2000-2004> Accessed on 13 October 2014; and Republic of South Africa, National Treasury. “Budget Review 2011”. Pretoria, 23 February 2011.

72 Batchelor, "South Africa's Arms Industry..." op. cit. 